\title{
Occurrence and threats of the medicinal leech (Hirudo medicinalis L.) in Poland (Annelida: Hirudinea)
}

\author{
Pawel BUCZYŃSKI*, Piotr DĄBKOWSKI**, Andrzej ZAWAL**, Radomir JASKULA***, \\ Grzegorz ToŃCZYK***, Michał GRABOWSKI***, Edyta BUCZYŃSKA****, \\ Krzysztof LEWANDOWSKI******, Dariusz JANICKI**, Stanisław CIOS*****, \\ Lech PIETRZAK*******, Przemyslaw MrowiŃSKI********, Joanna PAKULNICKA*******, \\ Aleksandra JABŁONSKA*** and Marek GUZIK *********
}

*Maria Curie-Skłodowska University, Department of Zoology, Akademicka 19, 20-033 Lublin, Poland; e-mail:pbuczyns@biotop.umcs.lublin.pl

**University of Szczecin, Department of Invertebrate Zoology and Limnology, Waska 13, 71-415 Szczecin, Poland; e-mail:piotrdab@sus.univ.szczecin.pl,zawal@univ.szczecin.pl,mollusca@wp.pl

***University of Lódź, Department of Invertebrate Zoology and Hydrobiology, Banacha 12/16, 90-237 Lódź, Poland; e-mail: tonczyk@biol.uni.lodz.pl,michalg@biol.uni.lodz.pl, radekj@biol.uni.lodz.pl,olapio@biol.uni.lodz.pl

****University of Agriculture in Lublin, Department of Zoology, Akademicka Str. 13, 20-033 Lublin, Poland; e-mail: eserafinek@wp.pI

*****Stryjeńskich 6/4,02-791 Warszawa, Poland; e-mail: stcios@hotmail.com

*****University of Warmia and Mazury, Department of Ecology and Nature Protection, Plac Lódzki 3, 10-719 Olsatyn,Poland; e-mail: joanna.pakulnicka@uwm.edu.pl,lewan@uwm.edu.pl

*******Mazurian University in Olecko, Department of Environmental Protection, Plac Zamkowy 5 , 19-400 Olecko,Poland; e-mail: lpietrzak@wp.pl

********Kombatantów 1/3, 74-320 Barlinek, Poland

*********Pedagogical University of Cracow, Department of Vertebrate Zoology, Pobrzezie 3, 31-054 Kraków,

Poland; e-mail: guzik@ap.krakow.pl

\begin{abstract}
The new data on the distribution of the medicinal leech (Hirudo medicinalis L.) in Poland, collected in the years 1999-2007 during several hydrobiological and batrachological studies in many regions of Poland, are presented. In total, 87 new records were found, which doubled the number of contemporary known localities. Habitat preferences and protected status of this species in Poland are discussed.
\end{abstract}

Key words: Hirudo medicinalis, Poland, distribution, protected status

\section{INTRODUCTION}

Medicinal leech (Hirudo medicinalis L. 1758) is one of the 44 leech species recorded till now from Poland (Jażdżewska 2004), and the only species of Hirudinea protected by Polish law (Dz. U. 2004). It is also the most endangered leech in Poland, and presently it is classified in VU category (vulnerable species) both in the Polish Red List and the Polish Red Data Book (Jażdżewska \& Wiedeńska 2002, 2004). Such situation is a result of habitat degradation and exploitation for medical purposes. Thus, further studies are necessary for planning an effective conservation strategy for this species.

Jażdżewska and Wiedeńska (2004) summarized number of localities of Hirudo medicinalis in Poland found in years 1975-2004. Some localities overlooked by these authors or records published after 2004 (including internet resources and angling literature) should be added to this number: Odra River in Szczecin (Rosińska et al. 2007); many water-bodies localized on 
Szczecin Lowland, near: Babin, Ziemomyśl, Nowogard, Warchlino, Szczecin (1997) (Zawal \& Dąbkowski 1999); peatbog of Baltic type: Warnie Bagno near Koszalin (Herbichowa et al. 2005); Wda River near Zimne Zdroje of Tuchola Forests (Motel 1997); forest inspectorate Borki, (RDLP 2006); surroundings of Latowicz near Mińsk Mazowiecki (Gajowniczek 2004); surroundings of Koczala near Miastko (Plan gospodarki 2004); Staw Florianiecki in Roztocze National Park (Lobocki 2006); oxbows of Wieprz River in Nadwieprzański Landscape Park, near villages: Milejów, Klarów, Kolonia Jaszczów (Marszal 2006); area of PrzeczyckoSiewierski Dam Reservoir (Goszcz et al. 2004); pond near Daniec (2002) (Wyszyński 2006); flooded fields near Sworawa in central Poland (Kamiński 2006); oxbows of Skawinka in Skawina, 1986-1986 (Schimscheiner et al. 1987); small water-body in Staniątki near Cracow (Guzik \& Schimscheiner 1984). H. medicinalis was also recorded from Oder River on the border between Poland and Germany (1992-1996), unfortunately no details about localities were given (Schöll 2003).

Medicinal leech can be determined in the field even by people not-specialising in Hirudinea (Utevsky \& Trontelj 2005). Many data about its occurrence and distribution can be easily collected by biologists - specialising in hydrobiology, entomology, batrachology, herpetology, and anglers or fishermen. Unfortuntely such data usually are not published. In present paper they are gathered and presented.

The main aim of this paper was to summarize knowledge about the distribution of medicinal leech and its habitats in Poland. We present many new localities for this species, especially in regions where Hirudo medicinalis was not collected until now, or in areas where it was recorded rarely or many years ago. Some comments about ecology and threats of this species are also given.

\section{METHODS}

The material was collected since 1999 to 2007, during various hydrobiological and batrachological projects in many regions of Poland - from lowlands to submontaneous areas. Leeches were collected using hydrobiological hand net and benthic dredge, some were also observed alive in different types of waters, or recorded on vertebrates. In some cases data were received from anglers and fishermen.

\section{RESULTS}

Medicinal leech was recorded from 87 new localities (Fig.1). The review of localities are ordered according to the physico-geographical division of Poland (Kondracki 2000).

\section{Szczecin Sea Coast Region (Pobrzeże Szczecińskie)}

1. Szczecin, $53^{\circ} 29^{\prime} \mathrm{N}, 14^{\circ} 28^{\prime} \mathrm{E}$. Water body near Glębokie Lake. Bottom composed of sand and mud with detritus, banks of the pond overgrown by reeds. Material: VI 1997, observation of $1 \mathrm{ex}$.

2. Szczecin-Warszewo, $53^{\circ} 29^{\prime} \mathrm{N}, 14^{\circ} 31^{\prime}$ E. Small water body with muddy bottom situated among agricultural fields. Banks overgrown by reeds and some trees. Material: 1999 and 2000 - several observations of usually few individuals.

3. West from the village Zaklodzie, $53^{\circ} 45^{\prime} \mathrm{N}, 1^{\circ} 01^{\prime} \mathrm{E}$. Peatbog in forest. Material: $17 \mathrm{~V} 2005,1$ ex.

4. $1 \mathrm{~km} \mathrm{SW}$ from the village Sikorki, $53^{\circ} 45^{\prime} \mathrm{N}, 15^{\circ} 01^{\prime} \mathrm{E}$. Small water body near the road from Sikorki to Glicko. Reed bed. Material: 10 VII 2005, 1 ex.

$5.1 \mathrm{~km} \mathrm{SE}$ from the village Sikorki, $53^{\circ} 46^{\prime} \mathrm{N}, 15^{\circ} 05^{\prime} \mathrm{E}$. Eutrophicated small water body among agricultural fields, shallow, drying in summer. Well developed phytolittoral zone. The pond belongs to a complex of small natural reservoirs in a swampy bed. Material: 10 VII 2005,7 exx.

$6.1 \mathrm{~km} \mathrm{~S}$ from the village Sikorki, $53^{\circ} 45^{\prime} \mathrm{N}, 15^{\circ} 05^{\prime} \mathrm{E}$. Small water body with rich aquatic vegetation, surrounded by willow and reed beds. Material: 5 V 2005, 1 ex., 10 VII 2005, 3 exx.

7. $\mathrm{S}$ from the village Piasek, $52^{\circ} 60^{\prime} \mathrm{N}, 14^{\circ} 48^{\prime}$ E. Small forest water body, shallow, surrounded by narrow reed zone. Material: 15 VII 2003, 1 ex. 
8. S from the village Piasek, $52^{\circ} 59^{\prime} \mathrm{N}, 14^{\circ} 48^{\prime} \mathrm{E}$. Two small water bodies with muddy bottoms surrounded by narrow reed zone and forest. Material: 15 VII 2003, 2 exx.

9. $1 \mathrm{~km}$ W from the village Karsk, $53^{\circ} 42^{\prime} \mathrm{N}, 14^{\circ} 58^{\prime} \mathrm{E}$. Small dystrophic water body in the alder forest with small reed bed. Material: 18 VII 2005, 1 ex.

10. Near the village Karsk, $52^{\circ} 57^{\prime} \mathrm{N}, 15^{\circ} 13^{\prime} \mathrm{E}$. Water body (surface of 1 ha, max depth $2 \mathrm{~m}$, muddy bottom, rich aquatic vegetation) surrounded by peat beds and forest. Bank with rich plant cover. Material: 18 VIII 2003, 1 ex

11. Area between villages Strzelewo and Czermnica, $53^{\circ} 42^{\prime} \mathrm{N}, 1^{\circ} 59^{\prime} \mathrm{E}$. Shallow, small water body surrounded by willow and reed bed. Material: 20 V 2005, 3 exx.

12. Area between villages Strzelewo and Czermnica, $53^{\circ} 42^{\prime} \mathrm{N}, 14^{\circ} 59^{\prime} \mathrm{E}$. Water body with rich aquatic vegetation, surrounded by moss covers, willow and reed beds. Material: 20 V 2005, 3 exx.

13. $0,5 \mathrm{~km} \mathrm{~N}$ from the village Trzechel, $53^{\circ} 45^{\prime} \mathrm{N}, 14^{\circ} 59^{\prime}$ E. Eutrophicated dam reservoir on Trzechelska Struga river, with narrow reed beds, surrounded by meadows. One of the many local small ponds occurred in agricultural terrain. Material: 17 VII 2005, 1 ex.

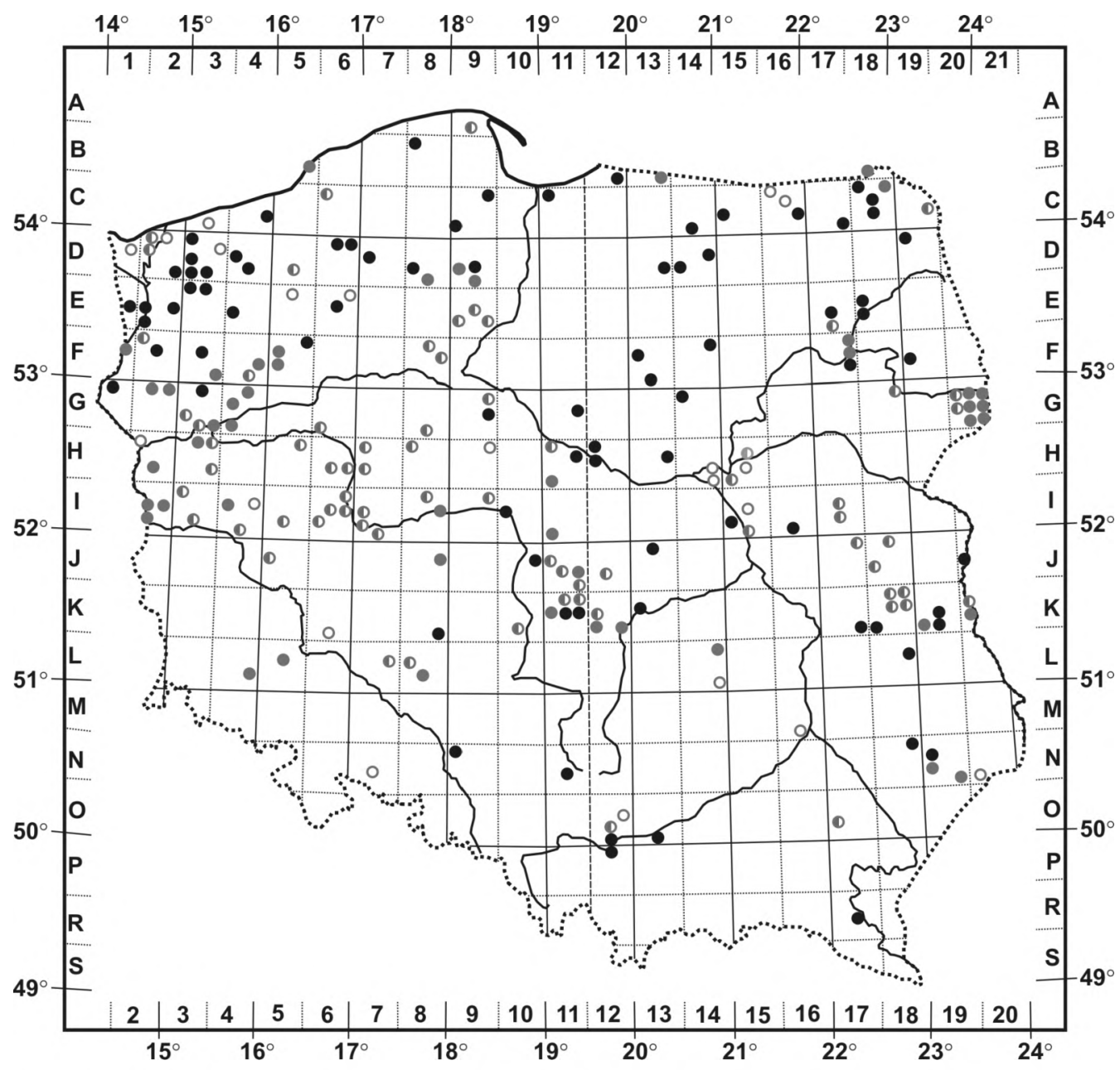

Fig. 1. Distribution of medicinal leech in Poland (COOR grid); empty circles - localities recorded till 1950, filled to the half - in 1951-1975, fully filled - after 1975; localities included in the Polish red data book (Jażdzewska \& Wiedeńska 2004) are given in grey; in black - original data, literature data overlooked by Jażdżewska \& Wiedeńska (2004) or data published after 2004. 
14. $0,7 \mathrm{~km} \mathrm{~N}$ from the village Trzechel, $53^{\circ} 45^{\prime} \mathrm{N}, 14^{\circ} 59^{\prime} \mathrm{E}$. Small water body with reed bed and rich aquatic vegetation. One of the many local small ponds occurred in agricultural landscape. Material: 17 VII 2005,3 exx.

15. $2 \mathrm{~km} \mathrm{~N}$ from Czermnica, $53^{\circ} 45^{\prime} \mathrm{N}, 14^{\circ} 58^{\prime} \mathrm{E}$. Small dystrophic lake with moss coverage, surrounded by narrow zone of reeds and forest. Rich aquatic vegetation. Material: 10 VII $2005,1 \mathrm{ex}$.

16. $0,5 \mathrm{~km}$ W from Krasnołęka, $53^{\circ} 36^{\prime} \mathrm{N}, 15^{\circ} 07^{\prime} \mathrm{E}$. Small water body among farmlands, with aquatic vegetation, surrounded by wide reed zone. Material: V-VII 2005 , several observations $1-3$ exx.

17. $0,5 \mathrm{~km} \mathrm{~W}$ from Krasnolęka, $53^{\circ} 36^{\prime} \mathrm{N}, 15^{\circ} 07^{\prime} \mathrm{E}$. Small water body near site 12 , between fields and forest with banks partly opened and overgrown with trees. Slightly dystrophic, subsequently eutrophicated. Phytolittoral zone poorly developed. Material: V-VII 2005, 1 ex.

18. $0,5 \mathrm{~km} \mathrm{~W}$ from Krasnołęka, $53^{\circ} 36^{\prime} \mathrm{N}, 15^{\circ} 07^{\prime}$ E. Small dystrophic water body on the forest edge. Well developed phytolittoral zone and surrounded by reedsand, willows. Material: V-VII 2005, few observations of 9-18 exx.

19. $2 \mathrm{~km} \mathrm{NE}$ from the village Unibórz, "Golczewskie Uroczysko" Natural Reserve, $15^{\circ} 04^{\prime} \mathrm{E}, 53^{\circ} 49^{\prime} \mathrm{N}$. Żabie Lake (surface of $1 \mathrm{ha}$, max depth 1,5 m, largely drying in summer) surrounded by peat bed. Material: $2 \mathrm{~V} 2006,3 \mathrm{exx}$.

$20.1 \mathrm{~km} \mathrm{~W}$ from Świerezewo, $53^{\circ} 41^{\prime} \mathrm{N}, 15^{\circ} 04^{\prime} \mathrm{E}$. Water body among farmlands, surrounded by wide willow and reed beds with some trees. Material: 5 V 2005, 4 exx, 7 VII 2005, 3 exx.

21. $2 \mathrm{~km} \mathrm{~N}$ from the village Jarchlino, $53^{\circ} 41^{\prime} \mathrm{N}, 15^{\circ} 15^{\prime} \mathrm{E}$. Dystrophic forest water body with well developed phytolittoral zone. The pond of a complex of small natural reservoirs in a swampy bed. Material: V-VII $2005,1 \mathrm{ex}$.

22. $\mathrm{N}$ of Osowo, $53^{\circ} 38^{\prime} \mathrm{N}, 15^{\circ} 16^{\prime} \mathrm{E}$. One of several small water bodies in an old park, with rich reed beds and aquatic vegetations. Material: $10 \mathrm{VII} 2005,1 \mathrm{ex}$.

23. $\mathrm{N}$ of Osowo, $53^{\circ} 38^{\prime} \mathrm{N}, 15^{\circ} 17^{\prime} \mathrm{E}$. Another water body of the same complex, phytolittoral zone well developed. Material: 10 VII 2005,1 ex.

24. $2 \mathrm{~km}$ SE from the village Slajsino, $53^{\circ} 39^{\prime} \mathrm{N}, 15^{\circ} 17^{\prime}$ E. Small water body surrounded by wide willow bed. Material: 10 VII 2005, 2 exx.

25. $1 \mathrm{~km} \mathrm{SE}$ from the village Stajsino, $53^{\circ} 39^{\prime} \mathrm{N}, 15^{\circ} 17^{\prime} \mathrm{E}$. Small water body, eutrophicated, placed on the border of forest and farmland, with wide reed zone. Material: 10 VII 2005, 1 ex.

26. SE part of village Osowo, $53^{\circ} 38^{\prime} \mathrm{N}, 15^{\circ} 17^{\prime} \mathrm{E}$. Fish pond surrounded by abandonded arable lands. Low water level, muddy bottom, rich aquatic vegetation, wide reed zone. Material: V-VII 2005, $1 \mathrm{ex}$.

27. Bienniczki, $53^{\circ} 38^{\prime} \mathrm{N}, 15^{\circ} 17^{\prime} \mathrm{E}$. Small water body among farmlands with reeds and several trees. Material: 10 VII 2005,1 ex.

28. $0,5 \mathrm{~km} \mathrm{~N}$ from villages Osowo and Bienniczki, $53^{\circ} 38^{\prime} \mathrm{N}, 15^{\circ} 17^{\prime} \mathrm{E}$. Complex of small post-glacial water bodies with rich reed beds and peatbogs, surrounded by beech, alder and willow forest. Material: 10 VII 2005,1 ex.

29. $1 \mathrm{~km}$ SE from the village Slajsino, $53^{\circ} 39^{\prime} \mathrm{N}, 15^{\circ} 14^{\prime} \mathrm{E}$. Small water body among farmlands near the road Wierzbięcin - Słajsino. Rich reed bed. Material: 10 VI 2005, 1 ex.

30. Ząbrowo, $53^{\circ} 51^{\prime} \mathrm{N}, 15^{\circ} 37^{\prime} \mathrm{E}$. Peatbog overgrown with reeds. Low water occurring in springs. Material: IVVII $2006,1 \mathrm{ex}$.

\section{Koszalin Region (Pobrzeże Koszalińskie)}

31. "Czarne Bagno" Nature Reserve near Lębork, 54³6' N, 17³8' E. Peatbog of Baltic type. Material: VII 2006, 1 ex.

\section{Gdańsk Region (Pobrzeże Gdańskie)}

32. Rybina, $54^{\circ} 17^{\prime} \mathrm{N}, 19^{\circ} 07^{\prime} \mathrm{E}$. Szkarpawa canal in Vistula delta, in the village. Stagnant water, muddy bottom, rich aquatic vegetation, banks overgrown with grass. Material:V 2000, 1 ex.

33. $1,5 \mathrm{~km} \mathrm{NW}$ from the village Świętochowo, $54^{\circ} 22^{\prime} 46^{\prime \prime} \mathrm{N}, 19^{\circ} 53^{\prime} 03^{\prime \prime}$ E. Small temporary water body among meadows, bottom with sand and mud, rich bank vegetation. Material: 19 VI 2006, few individuals observed in water at the area of some $100 \mathrm{~m}^{2}$.

\section{West Pomeranian Lakeland (Pojezierze Zachodniopomorskie)}

34. Ińsko, 53 $26^{\prime} \mathrm{N}, 1^{\circ} 32^{\prime} \mathrm{E}$. Ińsko Lake (surface 520.80 ha, max depth $41.7 \mathrm{~m}$ ) - mesotrophic waterbody. Material: 7 VII 2006, 1 ex. observed at night in the border zone between sandy beach and reeds.

35. Cieszyn, $53^{\circ} 48^{\prime} \mathrm{N}, 15^{\circ} 45^{\prime} \mathrm{E}$. Small, shallow water body among farmlands, eutrophicated with well developed phytolittoral zone. Material: IV-VII 2006, few observations of 2-3 exx.

36. Oparzno, $53^{\circ} 46^{\prime} \mathrm{N}, 15^{\circ} 42^{\prime} \mathrm{E}$. Small, shallow water body among farmlands, with well developed phytolittoral zone. Material: IV-VII 2006, two observations of 2 exx.

37. $0,5 \mathrm{~km} \mathrm{~S}$ from Bobęcińskie Wielkie Lake, $53^{\circ} 59^{\prime} \mathrm{N}, 16^{\circ} 51^{\prime} \mathrm{E}$. Small peatbog pond between Bobęcińskie Wielkie Lake and Oblica Lake, surrounded by old beech and swamp forests. Rich aquatic vegetation. Material: 14 VI 2002 , on the area of some $1 \mathrm{~m}^{2}$ about 20 exx. were observed

East Pomeranian Lakeland (Pojezierze Wschodniopomorskie)

38. "Jar Reknicy" Nature Reserve near Lapino, $5^{\circ} 16^{\prime} \mathrm{N}, 18^{\circ} 26^{\prime} \mathrm{E}$. Small water body among meadows, overgrown with vegetation. Material: 5 VIII $2004,1 \mathrm{ex}$. 
South Pomeranian Lakeland (Pojezierze Poludniowopomorskie)

39. $1 \mathrm{~km} \mathrm{~S}$ from village Sapólno Małe, $53^{\circ} 58^{\prime} \mathrm{N}, 16^{\circ} 44^{\prime} \mathrm{E}$. Bog surrounded by mixed forest, with some open water surface. Material: 10 VI 2002, 1 ex.

40. N from the village Swornegacie, $53^{\circ} 53^{\prime} \mathrm{N}, 17^{\circ} 30^{\prime} \mathrm{E}$. Zbrzyca River near Wytoczno Lake. Material: VII $2005,1 \mathrm{ex}$.

41. Watcz, $53^{\circ} 15^{\prime} \mathrm{N}, 16^{\circ} 30^{\prime} \mathrm{E}$. Small water body in the suburbs, with muddy bottom and reeds. Material: VIII 2003, observation of few individuals.

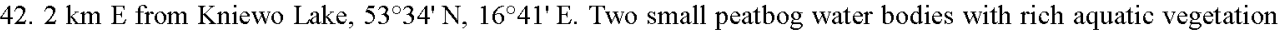

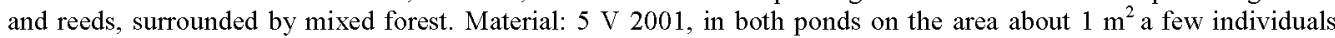
were noted.

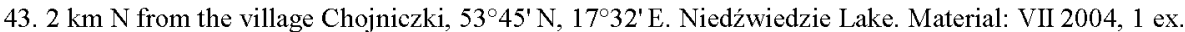

44. Bory Tucholskie National Park, 53 $50^{\prime} \mathrm{N}, 1^{\circ} 31^{\prime}$ E. Struga Siedmiu Jezior River, between Ostrowite and Zielone lakes. Stagnant fragment of the river with muddy bottom and rich vegetation. Material: 2 VII 2004, 1 ex.

\section{Chełmno-Dobrzyń Lakeland (Pojezierze Chełmińsko-Dobrzyńskie)}

45. Janoszyce, $52^{\circ} 40^{\prime} \mathrm{N}, 19^{\circ} 31^{\prime}$ E. Material: VI 2006, 2 exx.

46. Boguchwała, $52^{\circ} 50^{\prime} 07^{\prime \prime} \mathrm{N}, 1^{\circ} 23^{\prime} 25^{\prime \prime}$ E. Drainage canals on meadows. Very shallow, peat bottom, partly overgrown, banks covered with reeds. Material: 12 VII 2006, 2 exx.

\section{Torun-Eberswald Glacial Valley (Pradolina Toruńsko-Eberswaldzka)}

47. Nowy Duninów, $52^{\circ} 35^{\prime} \mathrm{N}, 19^{\circ} 28^{\prime} \mathrm{E}$. Włocławski Reservoir. Material: 2003, 1 ex.

48. Murzynowo, 5234' N, 19³1' E. Skrwa Prawa River at Włocławski Reservoir. Material: VI 2006, 1 ex.

\section{South Greater Poland Lowland (Nizina Południowowielkopolska)}

49. Dąbie, $52^{\circ} 05^{\prime} \mathrm{N}, 18^{\circ} 49^{\prime} \mathrm{E}$. Bzura River. Material: VI 2006, $1 \mathrm{ex}$

50. About $2 \mathrm{~km} \mathrm{~N}$ from the village Kościelec, $52^{\circ} 12^{\prime} \mathrm{N}, 18^{\circ} 34^{\prime} \mathrm{E}$. Warta River valley, water bodies on drainage canals. Very rich habitats, depth up to $2 \mathrm{~m}$, muddy bottom, rich aquatic vegetation. Material: 12 VI 2003, 2 exx. In this locality Hirudo medicinalis was often observed in different water bodies from early 90 s.

51. Lask-Kolumna, $51^{\circ} 36^{\prime} \mathrm{N}, 1^{\circ} 12$ E. Grabia River. Material: V 2006, 1 ex.

52. Lódź, $51^{\circ} 50^{\prime} \mathrm{N}, 19^{\circ} 28^{\prime}$ E. Ponds in Lagiewniki Forest. Muddy bottom covered with alder leaves. Surrounded by mixed forest. Material: IV 2001, 4 exx., III-IV 2002, 3 exx., IV 2004, 3exx., III-IV 2005, 2 exx. The individuals were found attached to mating common toads (Bufo bufo).

\section{Milicz-Głogów Depression (Obniżenie Milicko-Głogowskie)}

53. Poręby near Goszcz, 51 $26^{\prime} \mathrm{N}, 1^{\circ} 31^{\prime} \mathrm{E}$. Complex of aquaculture ponds. Muddy bottom, overgrown with reeds. Material: 2 V 2002, 1 ex. attached to concrete construction.

\section{North Mazovian Lowland (Nizina Północnomazowiecka)}

54. Księży Dwór, 5312' 35" N, 2003'33" E. Drainage canals on meadow at the right bank of Działdówka River. Muddy bottom, with patchy aquatic vegetation. Material: 12 VII 2006, 1 ex.

55. Proszkowo, $53^{\circ} 01^{\prime} 55^{\prime \prime}$ N, $20^{\circ} 11^{\prime} 12^{\prime \prime}$ E. Regulated section of Mlawka River. Sandy bottom with some detritus, rich aquatic vegetation, surrounded by meadows. Material: 18 VII 2006, 1 ex. and observation of 2 other individuals attached to sluice.

56. Krośnice, 52 58'03" N, 2029'57" E. Lydnia River. Very slow current, muddy bottom. Overgrown banks. Material: 15 VII 2006, 1 ex.

57. Baranowo $53^{\circ} 18^{\prime} 28^{\prime \prime} \mathrm{N}, 20^{\circ} 51^{\prime} 16^{\prime \prime} \mathrm{N}$. Drainage canals on meadows, very shallow, covered by Lemna, partly dried, with peat bottom. Material: 15 VII 2006, $1 \mathrm{ex}$.

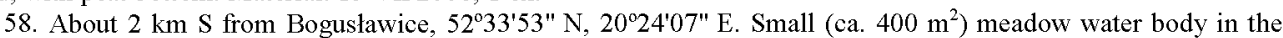
Naruszewka River valley. Depth to $0,5 \mathrm{~m}$, muddy bottom, almost completely overgrown with reeds. Material: $22 \mathrm{~V}$ $2006,1 \mathrm{ex}$.

\section{Central Mazovian Lowland (Nizina Środkowomazowiecka)}

59. Warszawa-Ursynów, $52^{\circ} 07^{\prime} \mathrm{N}, 21^{\circ} 02^{\prime} \mathrm{E}$. Small water body near crossroad of Stryjeńska and Wąwozowa streets. Depth up to $1 \mathrm{~m}$, drying in hot summers. Material: V 2002, 1 ex.

60. Budy Grabskie, "Rawka" Nature Reserve, 51 ${ }^{\circ} 43^{\prime}$ N, 21 $1^{\circ} 56^{\prime}$ E. Rawka River. Material: VI 2005, 2 exx. 


\section{Lublin Upland (Wyżyna Lubelska)}

62. Garbów, $51^{\circ} 29^{\prime} 05^{\prime \prime}$ N, $22^{\circ} 19^{\prime} 59^{\prime \prime}$ E. Eutrophic pond in a park. Bottom of mud, shore zone with very rich cattail community. Material: 18 VII 2007, very numerous exx. observed in the cattail community and found in the nest material of the Eurasian coot (Fulica atra).

Roztochia (Roztocze)

63. Roztochia National Park, 1,2 km SE from Zwierzyniec, $50^{\circ} 35^{\prime} 55^{\prime \prime} \mathrm{N}, 22^{\circ} 58^{\prime} 21^{\prime \prime}$ E. Echo ponds, surface less than 1 ha, bottom with sand and mud. Very rich reed community. Material: 14 VII 2003, 2 exx.

\section{Cracow Gate (Brama Krakowska)}

64. Kraków (Cracow) $-8^{\text {th }}$ District, 5001'24" N, 19²4'42" E. Vistula old river bed "Koło Tynieckie". Banks overgrown with reeds, rich aquatic vegetation. Deep to $1.5 \mathrm{~m}$, muddy bottom. Material: VII 2001, 1 ex.

\section{Central Beskid Upland (Pogórze Środkowobeskidzkie)}

65. Lesko, $49^{\circ} 27^{\prime}$ N, $22^{\circ} 19^{\prime}$ E. San River. Material: VI 2006, 1 individual attached to angler (A. Baranowski pers. comm.).

Lithuanian Lakeland (Pojezierze Litewskie)

66. Boczki, 54 $18^{\prime} 52^{\prime \prime}$ N, $22^{\circ} 30^{\prime} 53^{\prime \prime}$ E. Small permanent water body on the edge of a meadow and dry alder forest. Dystrophic, very shallow, bottom of dry sediments. Shore zone with rich vegetation of Carex. Material: 31 V 2007,2 exx.

67. Siedliska, $54^{\circ} 11^{\prime} 25^{\prime \prime} \mathrm{N}, 22^{\circ} 43^{\prime} 59^{\prime \prime} \mathrm{E}$. Small permanent water body on a meadow. Dystrophic, very shallow. Shore zone with rich vegetation. Material: 14 VIII 2007, numerous exx. collected by the use of a hydrobiological net and observed in a shallow water.

68. Skazdub Nowy, $54^{\circ} 06^{\prime} 58^{\prime \prime}$ N, $22^{\circ} 41^{\prime} 45^{\prime \prime}$ E. Moderately eutrophic Skadubek Lake, surface of ca. 20 ha. Bottom in the shore zone of sand and detritus, rich reed community. Material: 14 VIII 2007, 3 exx.

69. Kopanica, $53^{\circ} 58^{\prime} \mathrm{N}, 23^{\circ} 07^{\prime} \mathrm{E}$. Southern bay of Tobolowo Lake, very shallow with rich aquatic vegetation, surrounded by forest. Material: 3 VIII 2005, 1 ex.

\section{Masurian Lakeland (Pojezierze Mazurskie)}

70. Modliny, $54^{\circ} 01^{\prime} \mathrm{N}, 20^{\circ} 42^{\prime} \mathrm{E}$. Small stream with overgrown banks, in the deep gorge with numerous small ponds. Material: 18 VII 2003, 1 ex.

71. Żegoty, $54^{\circ} 02^{\prime} \mathrm{N}, 20^{\circ} 41^{\prime} \mathrm{E}$. Small water body on the forest margin, banks overgrown. Material: 4 VIII 2004,2 exx.

72. Trzeciaki, $54^{\circ} 06^{\prime} 56^{\prime \prime} \mathrm{N}, 21^{\circ} 06^{\prime} 35^{\prime \prime} \mathrm{E}$. Water body in swampy trough, used by anglers, surrounded by zones of reeds and alders. Water surface coverd with Lemna. Material: 22 VI 2006, 1 ex.

73. Olsztyn, $53^{\circ} 47^{\prime} \mathrm{N}, 20^{\circ} 28^{\prime}$ E. Eutrophic water body near Parkowa Street. Vegetation composed of flooded grasses and Potamogeton. Material: 9 V 2002, 1 ex.

74. Olsztyn, $53^{\circ} 45^{\prime} \mathrm{N}, 20^{\circ} 32^{\prime} \mathrm{E}$. Peatbog pond on the forest margin with overgrown banks, near Skanda Lake. Material: 2 V 2000,3 exx.

75. Olsztyn, $53^{\circ} 46^{\prime} \mathrm{N}, 20^{\circ} 27^{\prime}$ E. Kortówka River flowing from the Krzywe Lake - concrete banks, bottom with stones and mud, slow current. Material: 12 VII 2003, 3 individuals observed in water.

76. Olsztyn, 53 $46^{\prime}$ N, $20^{\circ} 29^{\prime}$ E. Water body at Żołnierska Street near hotel "Relaks" (old spring area). No vegetation, solid banks, trash. Material: 9 V 2006, 1 ex. on Triturus vulgaris.

77. Najdymowo, $53^{\circ} 52^{\prime} \mathrm{N}, 20^{\circ} 55^{\prime}$ E. Clay-pit (surface 0.5 ha, max depth $2 \mathrm{~m}$ ) near road Reszelski - Bartoszyce, surrounded by forest. It was used as a drinking place for cattle. Material: years 1997-1999, noted every month and during all vegetation seasons, always numerous individuals observed in water.

78. About $1 \mathrm{~km} \mathrm{~N}$ from the village Dziewiszewo, $54^{\circ} 02^{\prime} \mathrm{N}, 22^{\circ} 25^{\prime}$ E. Dobskie Lake. Material: VII 2002,2 individuals attached to floating old reed pieces.

North Podlasie Lowland (Nizina Północnopodlaska)

79. About $1 \mathrm{~km} \mathrm{~S}$ from Lawsk, $53^{\circ} 29^{\prime} 03^{\prime \prime} \mathrm{N} ; 2^{\circ} 19^{\prime} 23^{\prime \prime}$ E. Site placed in the complex of aquaculture ponds, overgrown with reeds, shallow (to $1 \mathrm{~m}$ ), muddy bottom. Material: $23 \mathrm{~V} 2006$, few individuals attached to reeds.

80. Near the village Brzozowa, $53^{\circ} 30^{\prime} 11^{\prime \prime} \mathrm{N}, 2^{\circ} 04^{\prime} 11^{\prime \prime}$ E. Drying old river bed, very shallow, overgrown with reeds, depth to $0.7 \mathrm{~m}$, muddy bottom. Material: $24 \mathrm{~V} 2006,1 \mathrm{ex}$.

81. Near the village Osowiec-Twierdza, $53^{\circ} 27^{\prime}$ N, $22^{\circ} 37^{\prime}$ E. Biebrza bogs, small water body near Carska Droga. Material: $1990,1 \mathrm{ex}$.

82. Near villages Grądy and Woniecko, $53^{\circ} 09^{\prime} 42^{\prime \prime}$ N, 22 $22^{\prime} 48^{\prime \prime}$ E. Dead arm of Narew River, shallow, muddy bottom, rich vegetation, surrounded by meadows. Material: 23 V 2006, 2 exx. 


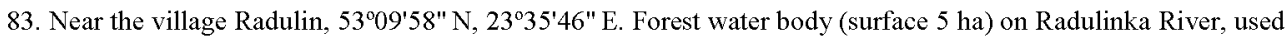
by anglers. No aquatic vegetation, muddy bottom, depth up to 1.5 meters, banks overgrown with reed beds. Material: $24 \mathrm{~V} \mathrm{2006,} 1$ ex.

\section{Western Polesie (Polesie Zachodnie)}

84. Jabłeczna, 51 $48^{\prime} 26^{\prime \prime} \mathrm{N}, 23^{\circ} 38^{\prime} 12^{\prime \prime}$ E. Eutrophic river bed of Bug River, on periodically flooded meadow. Bottom with sand and mud, very rich reed vegetation. Material: 25 VIII 2005, some individuals observed in littoral zone.

85. $1,5 \mathrm{~km} \mathrm{S-SE}$ from village Lubowież, $51^{\circ} 25^{\prime} \mathrm{N}, 23^{\circ} 18^{\prime} \mathrm{E}$. Lubowież Lake, eutrophicated pitbog lake, surrounded by moss coverage and willow beds. Material: V-IX 2003, few observations of numerous individuals swimming in littoral zone.

86. $2 \mathrm{~km}$ SE from the village Lubowież, $51^{\circ} 25^{\prime} \mathrm{N}, 23^{\circ} 18^{\prime} \mathrm{E}$. Lubowieżek Lake, peatbog lake, surrounded by moss coverage and reed beds. Material: V-IX 2003, few observations of few individuals swimming in littoral zone.

87. Sęków, $51^{\circ} 22^{\prime} \mathrm{N}, 23^{\circ} 15^{\prime}$ E. Permanent small dystrophic water body on the edge of Bagno Bubnów bog, overgrown with Carex. Material: 19 VII 2006, few individuals swimming in littoral zone.

Small water bodies group most of new localities of $H$. medicinalis (39\%), followed by fish aquacultures (16\%) and lakes (11\%). This species were also noted from 8 different types of aquatic habitats (Fig. 2).

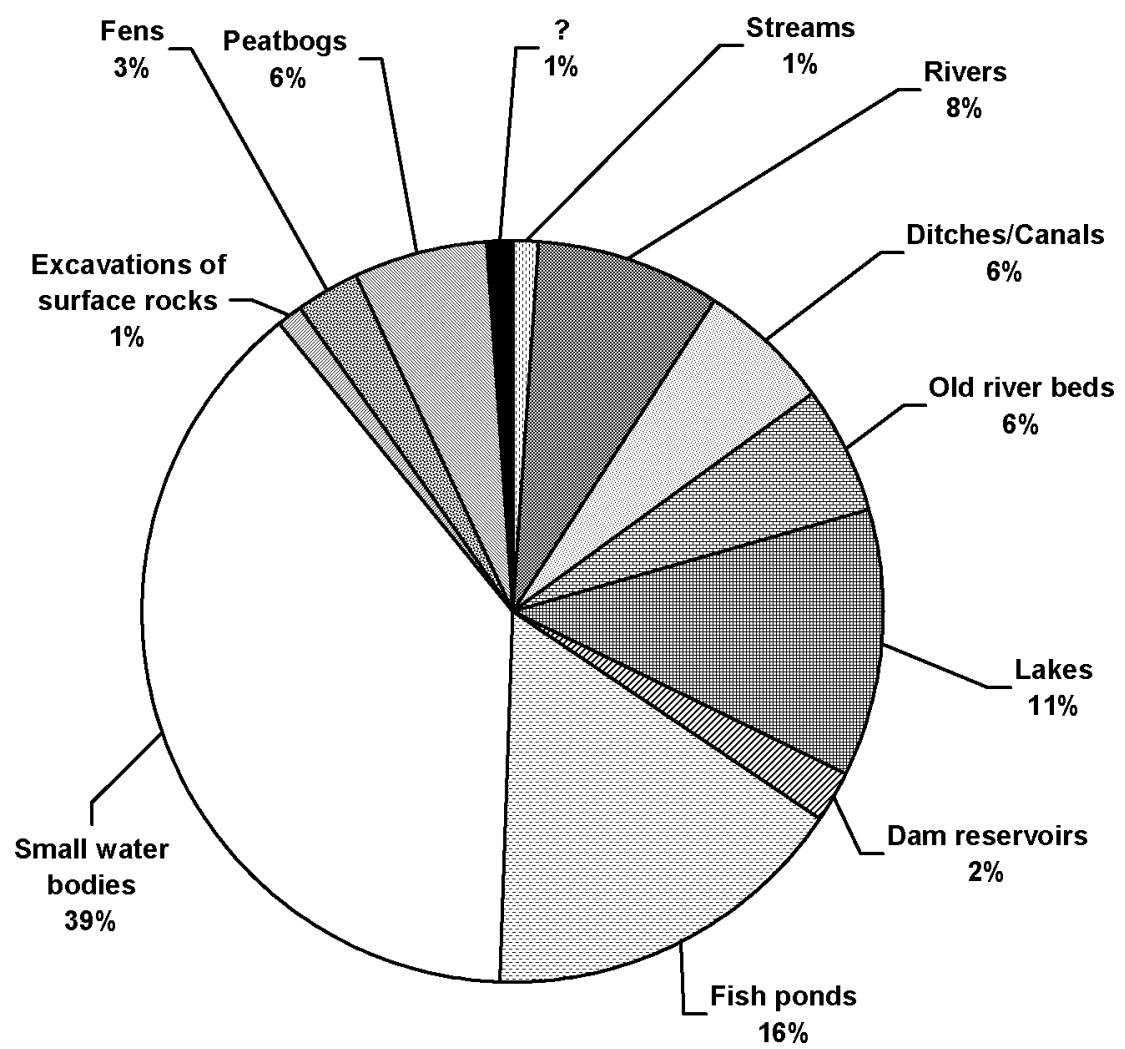

Fig. 2. Habitats represented by new localities of Medicinal Leech $(\mathrm{N}=83)$. ? - no data. 
Among 87 new records given in present paper, for 66 the data on basin trophy were available. Most of new localities can be characterized to be of eutrophic (60\%), and dystrophic $(35 \%)$ conditions. Oligotrophic and mesotrophic reservoirs grouped only $5 \%$ of localities (Fig. 3).

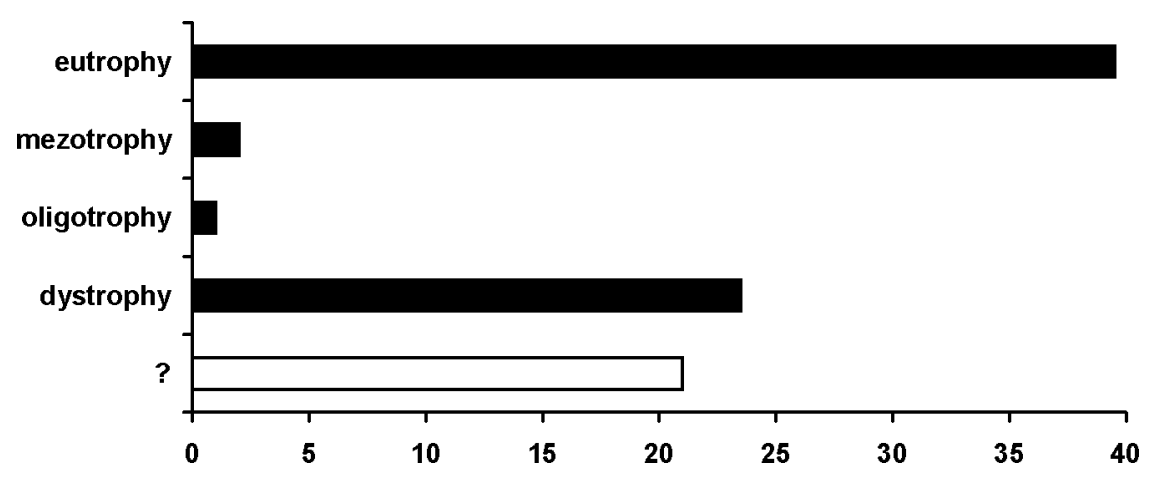

Fig. 3. Water trophy on new localities of medicinal leech $(\mathrm{N}=83)$, ? - no data.

\section{DISCUSSION}

Summarizing all the literature data and our new records, ca 160 localities of Hirudo medicinalis from Poland are known. If we note that the real number of localities where the species occurs is probably higher, the territory of Poland becomes an important refugee of this leech species for Central and Central-East Europe.

Records reported in this paper comprise over a half of all contemporary known localities of the medicinal leech in Poland. Particularly important are rich data from the Szczecin region and from north-eastern Poland - there were either no or very scarce or old data from these areas (e.g. Buczyński 2003, Buczyński et al. 2001). Also, interesting records come from central Poland, where the environment is highly altered due to human activity.

New records are located in many different regions of Poland. Most of the new data comes from northern part of Poland, including Littoral Szczecin Region, Masurian Lakeland and Suwalki Region. Numerous records are given also for central Poland, while the smallest number of information come from uplands and submontaneous areas. The highest elevation characterizing locality from San River near Lesko is about $430 \mathrm{~m}$ a.s.l. Next records from Cracow and Zwierzyniec village are placed on some $220-230 \mathrm{~m}$ a.s.1.

Jażdżewska and Wiedeńska (2004), based on very limited data, hypothesised that Hirudo medicinalis is widely distributed over the country, excluding the Carpathian and Sudety Mts. Our records compiled with older data support this statement (Fig. 1). The species is probably absent in most of the submontaneous and montaneous areas, however in lower localities is rather common. Generally $H$. medicinalis is widely distributed in Palaearctic and was also introduced to North America (Minelli 2004, Pawłowski 1968). Thus we may expect presence of this species in various parts of Poland, apart of those with altitudes exceeding $300-400 \mathrm{~m}$ a.s.1.

The locality no. 80 (Bug River) is interesting from the zoogeographical point of view, because Minelli (2004) recognizes records of the medicinal leech in Belarus as doubtful. Concerning our record and rich data on the occurrence of $H$. medicinalis in the Polish part of the Bialowieża Primaeval Forest, we can assume that its presence in Belarus is almost certain. 
Pawlowski (1968) discussed the human influence on the species distribution and abundance. From one hand its populations were exploited for medical reasons what could lead even to its extinction in some areas, from the other, used leeches were released to environment which could enhance its spread. Nowadays, threat from pathogens carried by the leeches limits its exploitation from natural sources, instead cultured animals are used (Thearle 1998, Whitaker et al. 2004).

As is seen in our records and in the literature data, medicinal leech prefers mostly small and warm basins. However it can be found also in almost all types of waterbodies, including postindustrial reservoirs (Jażdżewska \& Wiedeńska 2004, Pawłowski 1968, Wood \& Barker 2000). $H$. medicinalis avoids only springs, what may be related to its thermal demands. Also, the species inhabits water bodies with various sediments and trophic characteristics. It tolerates also low concentrations of oxygen. The spectrum of parasitized vertebrates is wide, with amphibians being important hosts (Merilä \& Sterner 2002, and own data).

It seems that the number and quality of small water-bodies in Poland is still sufficient for maintaining population of medicinal leech, and in the nearest future we should not expect any negative changes. Additionally, presence of this species in some heavily polluted waters (Odra River in Szczecin, see Rosińska et al. 2007) shows, that the species may be quite tolerant for altered environmental conditions.

Hirudo medicinalis was placed in the Red List of the IUCN in NT category ("near threatened") (IUCN 2004). However the data on its threats in neighbouring countries are very limited. In German federal states Saxony-Anhalt and Mecklenburg-Western Pomerania the species was ascribed to category 2 ("stark gefährdet") (Grosser 2004, Jueg 1999), equal to IUCN category EN ("endangered"). In Czech Republic it was classified as "critically endangered" (CR category) (Schenková \& Košel 2005), while in Lithuania as "vulnerable" (VU category) (Wikipedia Contributors 2007). Thus we may conclude that the species is endangered in Central and Western Europe, on the other hand taking into account our recent findings we may doubt whether its category VU ("vulnerable"), in Poland giving to this species by Jażdżewska \& Wiedeńska (2004) is not too high for Polish population (Jażdżewska \& Wiedeńska 2004).

According to IUCN criteria used in Polish Red Data Book (Glowaciński \& Nowacki 2004) VU category includes species which is likely to become endangered unless the circumstances (habitat loss, overexploitation) threatening its survival and reproduction improve. Lower categories are reserved for species with relatively large and stable populations of no direct threat, but still demanding attention due to factors present that could possibly endanger its survival. Based on the recent data we are of the opinion that medicinal leech in Poland should be ascribed at most to similar category as in the IUCN list - Lr/NT ("lower risk/near threatened").

In the future, the expansion of Hirudo verbana Carena, 1820 can be a problem associated with the protection of Hirudo medicinalis. This species is also used in medicine (Kutschera 2006) and sometimes set at large into the environment. $H$. verbana, clearly different from $H$. medicinalis by the plain green colouration of a ventral site of the body, has not been recorded in Poland so far, however, its wild populations are known from the Ukraine and Germany, with Mecklenburg-Western Pomerania land bordering on Poland among others (Grosser 2004, Jueg 1999, Minelli 2004). Moreover, the taxonomic status of this species has been unsure until recently - it has been regarded as the form or subspecies of H. medicinalis (Kutschera 2007, Kutschera \& Roth 2006). Siddal et al. (2007) proved, based on the molecular studies that Hirudo verbana is a separate species. Therefore, it is impossible to exclude certainly, that the part of old data about the occurrence of $H$. medicinalis in Poland actually refers to $H$. verbana, at least in case of the western part of the country. 


\section{REFERENCES}

BUCZYŃSKi P. 2003. Nowe stanowiska pijawki lekarskiej Hirudo medicinalis L. Chrońmy Przyrodę Ojczystą 59: $86-88$.

BUCZYŃSKI P., CZACHOROWSKI S. \& LECHOWSKI L. 2001. Niektóre grupy owadów wodnych (Odonata, Heteroptera, Coleoptera, Trichoptera) proponowanego rezerwatu "Torfowiska wiszące nad jeziorem Jaczno" i okolic: wyniki wstępnych badań Rocznik naukowy Polskiego Towarzystwa Ochrony Przyrody "Salamandra" 5: 27-42.

Dz. U. [Dziennik Ustaw] 2004. Rozporządzenie Ministra Środowiska z dnia 28 września 2004 r. w sprawie gatunków dziko występujących zwierząt objętych ochroną. Dziennik Ustaw 220, poz. 2237.

GAJOWNICZEK Z. T. 2004. Przyroda w Regionie Latowickim; http://www.republika.pl/latowiczbocian/4.htm.

GEOWACDSSKI Z. \& NOWACKI J. 2004. Zasady redakcyjne (Editorial principles). In: GEOWACINSKI Z., NOWACKI J. (eds), Polska czerwona księga zwierząt. Bezkręgowce. Instytut Ochrony Przyrody PAN, Akademia Rolnicza im. Augusta Cieszkowskiego, Kraków-Poznań: 14-20, 26-29.

Goszcz R., Kuzio B., Kuzio S., Grudzień I., Heljasz I., Hertlein A., Labryga B., Liberski W., Mustal H., NoszCZYK M., RYCHCIK K. \& STRASZ R. 2004. Program Ochrony Środowiska dla Miasta i Gminy Siewierz na lata 2004-2015; http:/www.siewierz.bip.info.pl/dokument.php?iddok=595\&idmp=36\&r=r

Grosser C. G. 2004. Rote Liste der Egel (Hirundinae) des Landes Sachsen-Anhalt. Rote Listen Sachsen-Anhalt. Berichte des Landesamtes für Umweltschutz Sachsen-Anhalt 39: 161-164.

GuZIK M. \& SCHIMSCHEINER L. 1984. Nowe stanowisko Hirudo medicinalis (L.) w Polsce południowej. Wszechświat 85: 209.

HeRBICHOWA M., PAWLACZYK P., KUJAWA-PAWLACZYK J. \& GAWRoNiski A. 2005. Natura 2000. Standardowy formularz danych dla Obszarów Specjalnej Ochrony (OSO) dla obszarów spełniających kryteria Obszarów O Znaczeniu Wspólnotowym (OZW) dla Specjalnych Obszarów Ochrony (SOO). PLH320047; http://natura2000.mos.gov.pl/natura2000/pl/dokumenty/n2/Warnie_Bagno.pdf

IUCN [International Union for Conservation of Nature] 2004. 2004 IUCN Red List of Threatened Species; www.iucnredlist.org

JAŻDŻEwska T. 2004. Pijawki Hirudinea. In: BogdaNowicz W., ChUdzicka E., PILIPIUK I. \& SkiBIíska E. (eds), Fauna Polski - Charakterystyka i wykaz gatunków. Vol. 1, pp. 4-6. Muzeum i Instytut Zoologii PAN, Warszawa.

JAŻDŻEWSKA T. \& WIEDEŃSKA J. 2002. Hirudinea Pijawki. In: GŁoWACIŃSKI Z. (ed.), Czerwona lista zwierząt ginących i zagrożonych w Polsce pp. 144-145. Instytut Ochrony Przyrody PAN, Kraków.

JAŻDŻEWSKA T. \& WIEDEŃSKA J. 2004. Pijawka lekarska - Hirudo medicinalis Linnaeus, 1758. In: GEOWACIŃSKI Z., NOWACKI J. (eds), Polska czerwona księga zwierząt. Bezkręgowce, pp. 33-34. Instytut Ochrony Przyrody PAN, Akademia Rolnicza im. A. Cieszkowskiego, Kraków - Poznań.

JUEG U. 1999. Egel und Krebsegel (Clitellata: Hirudinea u. Branchiobdellida) - zwei in Mecklenburg-Vorpommern faunistisch vernachlässigte Tiergruppen mit Vorschlägen zur Einschätzung ihrer Gefährdung. Naturschutzarbeit in Mecklenburg-Vorpommern 42: 68-76.

KAMחŃSKI K. Z. 2006. Nowe stanowisko pijawki lekarskiej Hirudo medicinalis Linnaeus, 1758 w środkowej Polsce. Chrońmy Przyrodę Ojczystą 62: 103-105.

KONDRACKI J. 2000. Geografia regionalna Polski. PWN, Warszawa, 442 pp.

KUTSCHERA U. 2006. The infamous blood suckers from Lacus Verbanus. Lauterbornia 56: 1-4.

KUTSCHERA U. 2007.The taxonomic status of dark-pigmented medicinal leeches of the genus the genus Hirudo (Hirudinea: Hirudinidae). Lauterbornia 59: 1-6.

KutscheRA U. \& ROTH M. 2006. Cocoon deposition and cluster formation in populations of the leech Hirudo verbana (Hirudenea: Hirudinidae). Lauterbornia 56: 5-13.

LOBOCKI J. 2006. 5.1. Stan zasobów leśnych. In: ŻELAZNY J., BUCZMA J., STRYCHARZ Z., PIEKARCZYK W. \& BABKIEWICZ Z. (eds), Raport o stanie środowiska województwa lubelskiego w 2005 roku, pp. 190-193. Biblioteka Monitoringu Środowiska, Lublin.

MARSZA£ K. 2006. Fauna Nadwieprzańskiego Parku Krajobrazowego; http://katrinh2o.republika.pl/

MERILÄ J. \& STERNER M. 2002. Medicinal leeches (Hirudo medicinalis) attacking and killing adult amphibians. Annales Zoologici Fennici 39: 343-349.

MiNELLI A. 2004. Fauna Europaea: Hirudinea. Fauna Europaea, version 1.1; http://www.faunaeur.org.

MOTEL W. 1997. Pijawka na nodze. Pstrag \& Lipień 5: 23-24.

PLAN GOSPODARKI ODPADAMI dla gminy Koczała na lata 2004 - 2011; bip.koczala.pl/plik.php?did=354.

RDLP [Regionalna Dyrekcja Lasów Państwowych w Białymstoku] 2006. Nadleśnictwo Borki - Ochrona lasu; http://www.bialystok.lasy.gov.pl/index.php?n=493

PAWŁOWSKI L. K. 1968. Katalog fauny Polski, XI, 3. Pijawki (Hirudinea). PWN, Warszawa, 94 pp.

RosińsKa B., RACZYŃSKA M., GRZESZCZYK-KOWALSKA A. \& CHOJNACKI J. C. 2007. Struktura ilościowojakościowa makrobentosu odcinka rzeki Odry Zachodniej w obrębie miasta Szczecina. In: CZERNLAWSKA-KUsZA I. (ed.), XIV Ogólnopolskie Warsztaty Bentologiczne „Hydromorfologiczna ocena ekosystemów wodnych”, Opole-Turawa, 10-12 maja 2007, p. 57. Lanko, Opole. 
SCHIMSCHEINER L., GUZIK M. \& GOLONKA P. 1987. Stanowisko pijawki lekarskiej Hirudo medicinalis (L.) w Skawinie. In: Streszczenia referatów. XIV Zjazd Polskiego Towarzystwa Zoologicznego, Szczecin 17-19 IX 1987, p. 197.

SCHENKOVÁ J. \& KOŠEL V. 2005. Hirudinea (pijavice). In: FARKAČ J., KRÁL D. \& ŠKORPíK M. (eds), Červený seznam ohrožených druhů České republiky. Bezobratlí, pp. 67-68. Agentura ochrany prírody a krajiny ČrR, Praha.

SCHÖLl F. 2003. Makrozoobentos Odry 1998-2001. Międzynarodowa Komisja Ochrony Odry przed Zanieczyszczeniem, Wrocław, $49 \mathrm{pp}$.

Siddal M. E., Trontelj P., Utevsky S. Y., Nkamany M. \& Macdonald III. K. S. 2007. Diverse molecular data demonstrate that commercially available medicinal leeches are not Hirudo medicinalis. Proceedings of the Royal Society B 274: $1481-1487$.

THEARLE M. J. 1998. Leeches in medicine. Australian and New Zealand Journal of Surgery 68: 292-295.

UTEVsKy S. Y. \& TRONTEL P. 2005. A new species of the medicinal leech (Oligochaeta, Hirudinida, Hirudo) from Transcaucasia and identification key for the genus Hirudo. Parasitology Research 98: 61-66.

WHTAKER I. S., RAO J., IZADI D. \& BUTLER P. E. 2004. Hirudo medicinalis: ancient origins of, and trends in the use of medicinal leeches throughout history. British Journal of Oral and Maxillofacial Surgery 42: 133-137.

WIKIPEDIA CONTRIBUTORS 2007. List of extinct and endangered species of Lithuania; http://en.wikipedia.org/wiki/List_of_extinct_and_endangered_animals_of_Lithuania \#Leech.

WOOD P. J. \& BARKER S. 2000. Old industrial mill ponds: a neglected ecological resource. Applied Geography 290: 65-81.

WYSZYŃSKI M. 2006. Świat zwierząt (World of animals); http: www.chrzastowice.pl/html/swiat zwierz.html.

ZAWAL A. \& DABKOWSKI P. 1999. Nowe stanowiska pijawki lekarskiej Hirudo medicinalis na Nizinie Szczecińskiej. Chrońmy Przyrodę Ojczystą 55: 111-112.

\section{STRESZCZENIE}

\section{[Występowanie i zagrożenie pijawki lekarskiej (Hirudo medicinalis L.) w Polsce]}

W oparciu o material zebrany podczas badań hydrobiologicznych i batrachologicznych realizowanych w różnych regionach Polski, podano 87 nowych stanowisk pijawki lekarskiej (Hirudo medicinalis L.). Pozwoliło to podwoić liczbę znanych współcześnie miejsc występowania tego zagrożonego gatunku w kraju. Wiele nowych stanowisk leży w regionach, w których pijawki lekarskiej nie wykazywano w ogóle lub od dlugiego czasu. Nowe stanowiska reprezentowaly 8 rodzajów środowisk wodnych, dominowaly: drobne zbiorniki, stawy rybne i jeziora. Większość zbiorników byla eutroficzna lub dystroficzna. Znaczaco uzupełniono mape rozmieszczenia gatunku przedstawioną w „Polskiej czerwonej księdze zwierząt". Nowe dane potwierdzają wcześniejsze hipotezy, że pijawka lekarska jest w Polsce znacznie częstsza, niż wynikało to $z$ dotychczasowych publikacji, i że wystepuje - nieraz stosunkowo często - w regionach, które stanowią „,białe plamy” na mapach jej rozmieszczenia. Unika jedynie obszarów górskich. Jednocześnie zaproponowano obniżenie jej kategorii zagrożenie w Polsce z kategorii wysokiego ryzyka - 'vulnerable' na kategorię niższego ryzyka - 'near threatened'. 